\title{
FARMING PRACTICES AND LIVELIHOOD STATUS OF NON-SALINE AND SALINE HOUSEHOLDS IN SOUTHERN BANGLADESH
}

\author{
M.T. Uddin ${ }^{1 *}$, W. Erskine ${ }^{2}$, A.R. Dhar ${ }^{1}$, M.I. Shishir ${ }^{1}$ and M.G. Neogi ${ }^{3}$ \\ ${ }^{1}$ Department of Agricultural Economics, Bangladesh Agricultural University \\ Mymensingh, Bangladesh \\ ${ }^{2}$ School of Agriculture and Environment, University of Western Australia, Australia \\ ${ }^{3}$ University of Western Australia, Australia
}

\begin{abstract}
The study examined the farming practices and livelihood status of farm households in seven districts of Southern Bangladesh. Majority of the farmers in non-saline and saline areas followed the cropping pattern of Fallow - Aman rice - Pulses and Fallow - Aman rice - Fallow, respectively. Cropping intensity was higher in non-saline areas (220.0\%) compared to saline areas (101.7\%). Profitability of major crops was much higher in non-saline areas compared to saline areas. Based on the poverty indicators, the proportion of deprived households was 41.7 and $56.0 \%$ in non-saline and saline areas, respectively. The study recommended that in saline areas, rain water reservoirs should be developed in cooperative way and availability of electricity use should be facilitated to use light irrigation pumps in the crop field from the nearest fresh water reservoir. In addition, canal reform should be done and leasing arrangement of water canals should be stopped to get farmers' access for irrigation purpose. Moreover, salt-tolerant and short duration pulse and wheat should be introduced in order to improve livelihood of saline farm households in Bangladesh.
\end{abstract}

Keywords: Crop Intensification; Farming practices; Poverty Situation; Salinity

\section{INTRODUCTION}

The coastal zone of Southern Bangladesh has a significant place in the country's economy (Ahsan, 2013). Nearly 40 million people of the coastal areas of Bangladesh depend on agriculture (BBS, 2015). In this region, agricultural activity centres on the annual cropping of monsoonal rice. Cropping in the dry rabi season is conditioned by land topography, drainage, soil salinity and irrigation availability (ACIAR, 2011). In the rainfed lands, dry-season cultivation is limited by the profitability of traditional

* Corresponding author: tajbau@yahoo.com 
cultivation of pulses (DAE, 2015). Nonetheless where limited irrigation is possible, wheat is a profitable low risk option (Kabir and Rawson, 2011). Around one third of the farmers in the coastal areas are now cultivating only one crop in a calendar year, i.e., Aman rice during monsoon while most of the cultivable lands remain almost barren in dry season (Hossain, 2016). For socioeconomic constraints, the majority of the region can't afford animal protein and as such, have to depend on plant protein, bulk of which comes from pulses. The excellent nutrition value of pulses is highly complementary to a cereal-based diet in developing countries (UNB, 2017). From the viewpoint of environment, monocropping along with imbalanced use of inorganic fertilizers, pesticides and intensive use of land without application of organic fertilizers have led to a deterioration of soil quality and fertility (Uddin et al., 2016). To combat monocropping, pulses and wheat can contribute to diversification of ricebased systems productivity in Southern Bangladesh.

Importance of the above stated modality has been portrayed in a number of literatures which are: Hasan et al. (2018) found that adoption of climate smart agriculture (CSA) practices was positively associated with household food security in Southern Bangladesh in terms of per capita annual food expenditure. Hossain and Majumder (2018) stated that most of the rural coastal people of Bangladesh were hard poor in which women were major in portion and contributed to ensure food security for the entire family. Shoaib (2013) revealed that mixed land use like transplanted Aman and fish or Boro-transplanted Aman or Boro-fish were the popular forms of land use in the coastal zone of Bangladesh. It is evident from the reviews that there is lack of study incorporating the farming practices, profitability of farm enterprises and overall poverty situation for both farmers of non-saline and saline areas. In view of the above perspectives, the current research focused on farming practices, crop intensification, profitability in saline and non-saline areas Southern Bangladesh.

\section{MATERIALS AND METHODS}

Study areas and sample size

The study was conducted at seven districts of Southern Bangladesh. Based on the level of soil salinity, five upazilas from these districts were selected as non-saline areas and seven upazilas were selected as saline areas. A total of 500 farmers (i.e., 200 from non-saline areas and 300 from saline areas) were investigated following stratified random sampling technique. The area-wise sample distribution is represented in Table 1 as follows: 
Table 1. Selection of study areas and sample size

\begin{tabular}{|c|c|c|c|c|c|c|}
\hline Districts & Sub-districts & Sample & Districts & Sub-districts & Sample & Total sample \\
\hline \multicolumn{3}{|c|}{ Non-saline areas } & \multicolumn{3}{|c|}{ Saline areas } & \multirow{9}{*}{500} \\
\hline \multirow{2}{*}{ Barguna } & \multirow{2}{*}{ Betagi } & \multirow{2}{*}{30} & \multirow{2}{*}{ Barguna } & Sadar & 30 & \\
\hline & & & & Amtali & 20 & \\
\hline Patuakhali & Sadar & 50 & Patuakhali & Kalapara & 50 & \\
\hline Khulna & Phultala & 50 & Khulna & Batiaghata & 50 & \\
\hline \multirow{2}{*}{ Barisal } & \multirow{2}{*}{ Babuganj } & \multirow{2}{*}{30} & \multirow{2}{*}{ Satkhira } & Sadar & 50 & \\
\hline & & & & Kaligonj & 50 & \\
\hline Jhalokathi & Nolcity & 40 & Bhola & Charfashion & 50 & \\
\hline Sub-total & & 200 & Sub-total & & 300 & \\
\hline
\end{tabular}

\section{Data collection and analysis}

Primary data were collected through questionnaire survey, focus group discussions (FGD) and key informant interviews (KII) with local stakeholders. For analyzing the data, a combination of descriptive statistics, mathematical and statistical techniques were used to achieve the objectives and to get the meaningful result.

\section{Descriptive statistics}

Data on farming practices in non-saline and saline areas were presented mostly in the tabular (i.e., sum, average, percentages, etc.) and graphical (i.e., figures and graphs) forms.

\section{Crop intensification index}

To measure the cropping intensity, the following formula was used for calculation:

Cropping intensity $=\left(\right.$ Area $_{\mathrm{GC}} \div$ Area $\left._{\mathrm{NC}}\right) \times 100$

Where,

Area $_{\mathrm{GC}}=$ Gross cropped area (ha); and Area $_{\mathrm{NC}}=$ Net cropped area (ha).

Profitability of major crops

Profitability of major crops production was measured in terms of gross return, gross margin, net return and benefit cost ratio (undiscounted). The formulas needed for the calculation of profitability were discussed as follows (Stigler, 1994; Dillon and Hardaker, 1993):

$$
\mathrm{GR}=\mathrm{P} \times \mathrm{Q} ; \mathrm{GM}=\mathrm{GR}-\mathrm{TVC} ; \mathrm{NR}=\mathrm{GR}-(\mathrm{TFC}+\mathrm{TVC}) ; \mathrm{BCR}=\mathrm{GR} \div
$$
$(\mathrm{TFC}+\mathrm{TVC})$

Where,

GR $=$ Gross return; $\mathrm{P}=$ Sales price of the product $(\mathrm{Tk}.) ; \mathrm{Q}=$ Yield per hectare (unit); GM = Gross margin; TVC = Total variable cost; NR = Net return; $\mathrm{TFC}=$ Total fixed cost (Tk.); and $\mathrm{BCR}=$ Benefit cost ratio. 
Multidimensional poverty index

Multidimensional poverty index (MPI) is an index designed to measure the intensity of poverty (Uddin and Dhar, 2017). It comprises three equally weighted poverty dimensions; health, education and living standards. The health dimension is measured by the two equally weighted indicators, nutrition and child mortality. Education is captured by the two equally weighted indicators, years of schooling and child enrolment. Living standards are measured by the six equally weighted indicators; cooking fuel, sanitation, water, electricity, floor and assets. The following formula was used to appraise the intensity of poverty:

$$
\text { Intensity of poverty }=\Sigma \mathrm{ck} \times 100
$$

Where, the indicators.

$$
\mathrm{c}=\text { Households deprived of the indicators; and } \mathrm{k}=\text { Weighted score of }
$$

\section{RESULTS AND DISCUSSION}

Major agronomic and cropping practices

Table 2 depicts the major agronomic and cropping practices followed by the farmers in the study areas. In the non-saline areas, majority of the farmers followed the cropping patterns of Fallow - Aman rice - Pulses, Fallow - Aman rice - Boro rice and Aus rice - Aman rice - Pulses whereas in saline areas, most of the farmers followed the cropping patterns of Fallow - Aman rice - Fallow, Fallow - Aman rice - Pulses and Fallow - Aman rice - Chili/Maize/Rabi crops. These cropping patterns reveal that there is a lack of dry season crops in the study areas. In this regard, Shahidullah et al. (2006) stated that only a single cropping pattern of single Fallow Fallow - T. Aman rice occupied 35\% of total cropped area in the South East coastal region of Bangladesh. Most of the farmers in non-saline areas cultivated crop through manual irrigation (55\% farmers) whereas in saline areas, majority of the farmers (78\% farmers) were depended on rainfed irrigation.

Table 2. Major agronomic and cropping practices in the study areas

\begin{tabular}{ll|l|l|l|c}
\hline \multirow{2}{*}{} & \multirow{2}{*}{ Particulars } & \multicolumn{4}{c}{ Study areas } \\
\cline { 3 - 6 } & \multicolumn{2}{|c|}{ Non-saline } & \multicolumn{2}{c}{ Saline } \\
\cline { 3 - 6 } & $\begin{array}{c}\text { No. of } \\
\text { farmers }\end{array}$ & $\begin{array}{c}\% \text { of } \\
\text { farmers }\end{array}$ & $\begin{array}{c}\text { No. of } \\
\text { farmers }\end{array}$ & $\begin{array}{c}\% \text { of } \\
\text { farmers }\end{array}$ \\
\hline & Fallow - Aman rice - Pulses & 159 & 79.5 & - & - \\
$\begin{array}{l}\text { Major } \\
\text { cropping } \\
\text { pattern }\end{array}$ & $\begin{array}{l}\text { Fallow - Aman rice - Boro } \\
\text { rice }\end{array}$ & 130 & 65.0 & - & - \\
& $\begin{array}{l}\text { Aus rice - Aman rice - } \\
\text { Pulses }\end{array}$ & & & & - \\
\hline
\end{tabular}




\begin{tabular}{|c|c|c|c|c|c|}
\hline & \multirow{3}{*}{ Particulars } & \multicolumn{4}{|c|}{ Study areas } \\
\hline & & \multicolumn{2}{|c|}{ Non-saline } & \multicolumn{2}{|c|}{ Saline } \\
\hline & & $\begin{array}{l}\text { No. of } \\
\text { farmers }\end{array}$ & $\begin{array}{c}\% \text { of } \\
\text { farmers }\end{array}$ & $\begin{array}{l}\text { No. of } \\
\text { farmers }\end{array}$ & $\begin{array}{l}\% \text { of } \\
\text { farmers }\end{array}$ \\
\hline & $\begin{array}{l}\text { Fallow }- \text { Aman rice }- \\
\text { Fallow }\end{array}$ & - & - & 211 & 70.3 \\
\hline & Fallow - Aman rice - Pulses & - & - & 122 & 40.7 \\
\hline & $\begin{array}{l}\text { Fallow }- \text { Aman rice - } \\
\text { Chili/Maize/Rabi crops }\end{array}$ & - & - & 36 & 12.0 \\
\hline \multirow{2}{*}{$\begin{array}{l}\text { Land } \\
\text { topography }\end{array}$} & Sandy loam soil & 116 & 58.0 & 190 & 63.3 \\
\hline & Loam soil & 84 & 42.0 & 110 & 36.7 \\
\hline \multirow{3}{*}{$\begin{array}{l}\text { Temperature } \\
\text { and rainfall }\end{array}$} & High & 43 & 21.5 & 104 & 34.8 \\
\hline & Medium & 144 & 72.0 & 166 & 55.2 \\
\hline & Low & 13 & 6.5 & 30 & 10.0 \\
\hline \multirow{2}{*}{$\begin{array}{l}\text { Irrigation } \\
\text { technique }\end{array}$} & Irrigated & 30 & 55.0 & 66 & 22.0 \\
\hline & Rainfed & 170 & 45.0 & 234 & 78.0 \\
\hline
\end{tabular}

Source: Field survey, 2018.

\section{Analysis of crop intensification}

Cropping intensity is explained as the number of crops grown in a given cropland per year (Bhaskar, 2009). The whole process is named as crop intensification. Considering the gross and net cropped area, the study found that cropping intensity was higher for the farmers in non-saline areas (220\%) than saline areas $(101.7 \%)$ (Table 3). The results implied that farmers in non-saline areas grow crops for nearly 2.2 times per year in a particular crop land but it was 1.1 times in case of farmers in saline areas. The result is quite similar with Uddin and Dhar (2018) where the author found higher cropping intensity in case of government input supported households $(228.6 \%)$ compared to the non-supported households (172\%).

Table 3. Crop intensification index (CII)

\begin{tabular}{l|l|l}
\hline \multirow{2}{*}{ Particulars } & \multicolumn{2}{|l}{ Study areas } \\
\cline { 2 - 3 } & Non-saline & Saline \\
\hline Gross cropped area (ha) & 0.66 & 0.61 \\
Net cropped area (ha) & 0.30 & 0.60 \\
Cropping intensity (\%) & 220.0 & 101.7 \\
\hline
\end{tabular}

Source: Authors' estimation, 2018. 


\section{Profitability of major crops}

For calculating profitability of major crops, total production cost composed of variable and fixed costs was taken into consideration. The components of variable cost were: i) human labour; ii) power tiller; iii) seed/seedlings; iv) fertilizers; v) irrigation; vi) herbicides and insecticides and vii) fencing. Table 4 represents that total variable cost of farmers in non-saline areas was Tk. 97463, Tk. 37284, Tk. 53144 and Tk. 16416 for Aus rice, Aman rice, Boro rice and pulses production, respectively. On the other hand, total variable cost of farmers in saline areas was Tk. 37190, Tk. 22267, Tk. 168793 and Tk. 43291 for Aman rice, pulses, vegetables and spices production, respectively. Fixed cost items for crop production were: i) land use cost; ii) interest on operating capital; and iii) depreciation cost. It is seen from Table 4 that total fixed cost of farmers in non-saline was Tk. 14348, Tk. 6798, Tk. 11978 and Tk. 5382 for Aus rice, Aman rice, Boro rice and pulses production, respectively whereas in saline areas, it was Tk. 6902, Tk. 5954, Tk. 16537 and Tk. 11586 for Aman rice, pulses, vegetables and spices production, respectively. Total cost of Aus rice, Aman rice, Boro rice and pulses production in case of farmers in non-saline was Tk. 111991, Tk. 44082, Tk. 65122 and Tk. 21798, respectively. In saline areas, total cost of farmers for Aman rice, pulses, vegetables and spices production was estimated at Tk. 44092, Tk. 28221, Tk. 185330 and Tk. 54877, respectively.

Table 4. Cost of major crop production in the study areas

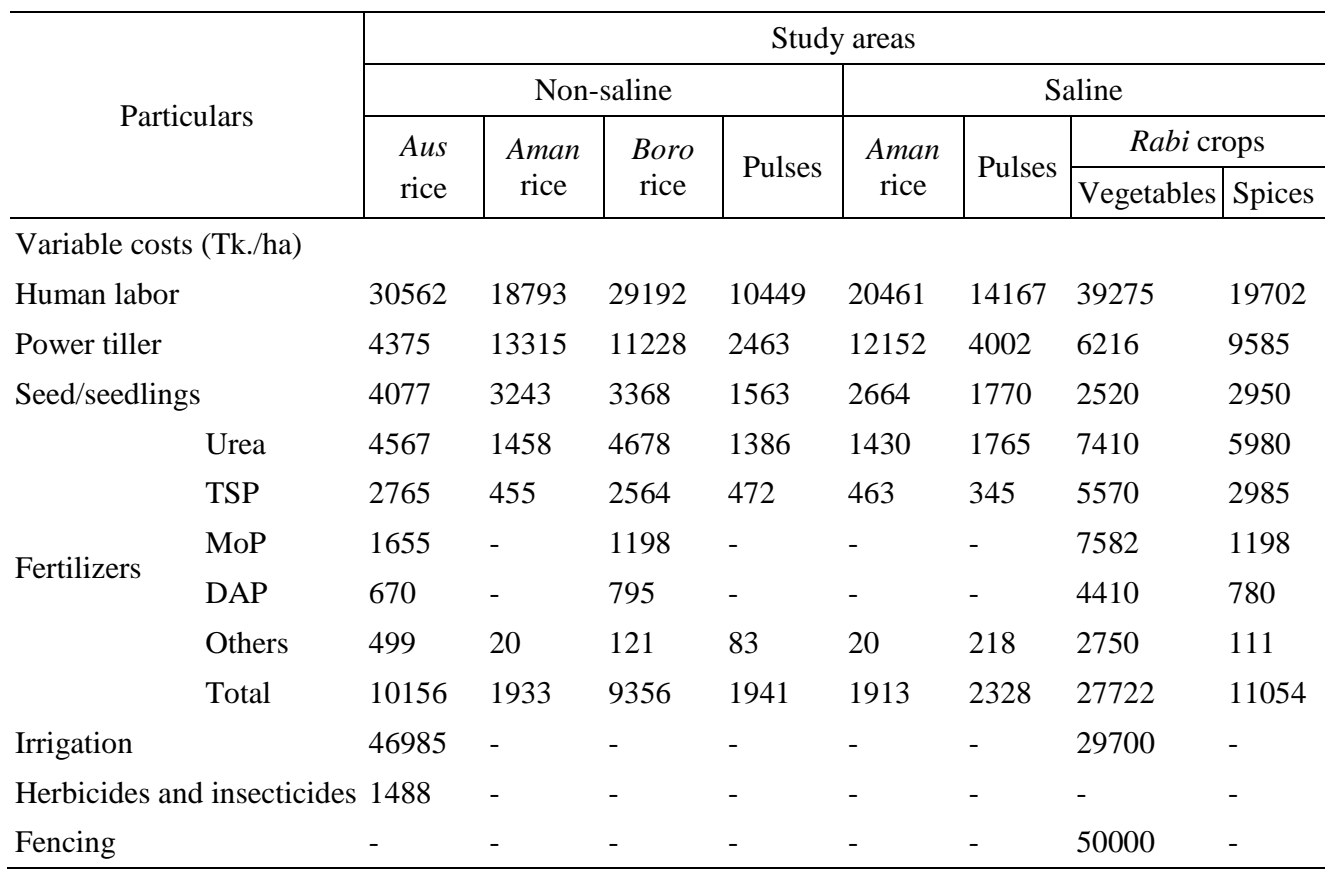




\begin{tabular}{|c|c|c|c|c|c|c|c|c|}
\hline \multirow{4}{*}{ Particulars } & \multicolumn{8}{|c|}{ Study areas } \\
\hline & \multicolumn{4}{|c|}{ Non-saline } & \multicolumn{4}{|c|}{ Saline } \\
\hline & \multirow{2}{*}{$\begin{array}{l}A u s \\
\text { rice }\end{array}$} & \multirow{2}{*}{$\begin{array}{c}\text { Aman } \\
\text { rice }\end{array}$} & \multirow{2}{*}{$\begin{array}{c}\text { Boro } \\
\text { rice }\end{array}$} & \multirow{2}{*}{ Pulses } & \multirow{2}{*}{$\begin{array}{l}\text { Aman } \\
\text { rice }\end{array}$} & \multirow{2}{*}{ Pulses } & \multicolumn{2}{|c|}{ Rabi crops } \\
\hline & & & & & & & Vegetables & Spices \\
\hline i. Total variable cost & 97643 & 37284 & 53144 & 16416 & 37190 & 22267 & 168793 & 43291 \\
\hline \multicolumn{9}{|l|}{ Fixed costs (Tk./ha) } \\
\hline Land use cost & 8732 & 4366 & 8617 & 4473 & 4179 & 4400 & 7552 & 8655 \\
\hline $\begin{array}{l}\text { Interest on operating } \\
\text { capital }\end{array}$ & 4557 & 1740 & 2595 & 659 & 1923 & 1005 & 7815 & 2097 \\
\hline Depreciation cost & 1059 & 692 & 766 & 250 & 800 & 549 & 1170 & 834 \\
\hline ii. Total fixed cost (Tk./ha) & 14348 & 6798 & 11978 & 5382 & 6902 & 5954 & 16537 & 11586 \\
\hline iii. Total cost (Tk./ha) & 111991 & 44082 & 65122 & 21798 & 44092 & 28221 & 185330 & 54877 \\
\hline
\end{tabular}

Source: Authors' estimation, 2018.

Gross return from crop production included the monetary value of physical output obtained from the production process. Gross return from Aus rice, Aman rice, Boro rice and pulses production was Tk. 137749, Tk. 55543, Tk. 74890 and Tk. 39454 for the farmers in non-saline areas; and from Aman rice, pulses, vegetables and spices production was Tk. 54233, Tk. 48540, Tk. 398460 and Tk. 108656 for the farmers in saline areas, respectively (Table 5). Gross margin of the farmers in non-saline areas was Tk. 40106, Tk. 18259, Tk. 21746 and Tk. 23038 from Aus rice, Aman rice, Boro rice and pulses production; and in saline areas it was Tk. 17043, Tk. 26273, Tk. 229667 and Tk. 65365 from Aman rice, pulses, vegetables and spices production, respectively. From Table 5, it is seen that net return from Aus rice, Aman rice, Boro rice and pulses production in non-saline areas was Tk. 25758, Tk. 11461, Tk. 9768 and Tk. 17656 while in saline areas, and it was Tk. 10141, Tk. 20319, Tk. 213130 and Tk. 53779 from Aman rice, pulses, vegetables and spices production, respectively.

BCR from Aus rice, Aman rice, Boro rice and pulses production in non-saline areas was $1.23,1.26,1.15$ and 1.81, respectively (Table 5). On the contrary, BCR from Aman rice, pulses, vegetables and spices production in saline areas was $1.23,1.72$, 2.15 and 1.98 , respectively. The results imply that farmers in non-saline and saline areas received Tk. 123, Tk. 126, Tk. 115 and Tk. 181; and Tk. 123, Tk. 172, Tk. 215 and Tk. 198 for Aus rice, Aman rice, Boro rice and pulses production; and Aman rice, pulses, vegetables and spices production in return from investing Tk. 100, respectively. Nahar and Hamid (2016) found the similar result where the authors evaluated the economic impact of soil salinity on paddy production in South-West region of Bangladesh. The study revealed that net return figures turned out to be Tk. 10635 and 7762 per acre in low and high saline regions, respectively. 
Table 5. Return from major crop production in the study areas

\begin{tabular}{|c|c|c|c|c|c|c|c|c|}
\hline \multirow{4}{*}{ Particulars } & \multicolumn{8}{|c|}{ Study areas } \\
\hline & \multicolumn{4}{|c|}{ Non-saline } & \multicolumn{4}{|c|}{ Saline } \\
\hline & \multirow{2}{*}{$\begin{array}{l}\text { Aus } \\
\text { rice }\end{array}$} & \multirow{2}{*}{$\begin{array}{c}\text { Aman } \\
\text { rice }\end{array}$} & \multirow{2}{*}{ Boro rice } & \multirow{2}{*}{ Pulses } & \multirow{2}{*}{$\begin{array}{c}\text { Aman } \\
\text { rice }\end{array}$} & \multirow{2}{*}{ Pulses } & \multicolumn{2}{|c|}{ Rabi crops } \\
\hline & & & & & & & Vegetables & Spices \\
\hline Productivity (maund/ha) & 157 & 53 & 96 & 39 & 50 & 37 & 996 & 102 \\
\hline Price (Tk./maund) & 838 & 772 & 700 & 1012 & 808 & 1312 & 400 & 887 \\
\hline $\begin{array}{l}\text { Return from main product } \\
\text { (Tk./ha) }\end{array}$ & 131566 & 40916 & 67200 & 39454 & 40400 & 48540 & 398460 & 90474 \\
\hline $\begin{array}{l}\text { Return from } \\
\text { (Tk./ha) }\end{array}$ & 6183 & 14627 & 7690 & - & 13833 & - & - & 18182 \\
\hline iv. Gross return (Tk./ha) & 137749 & 55543 & 74890 & 39454 & 54233 & 48540 & 398460 & 108656 \\
\hline $\begin{array}{l}\text { v. Gross margin (Tk./ha) } \\
\text { (iv - i) }\end{array}$ & 40106 & 18259 & 21746 & $2303=8$ & 17043 & 26273 & 229667 & 65365 \\
\hline $\begin{array}{l}\text { vi. Net return (Tk./ha) } \\
\text { (iv - iii) }\end{array}$ & 25758 & 11461 & 9768 & 17656 & 10141 & 20319 & 213130 & 53779 \\
\hline $\begin{array}{l}\text { vii. Benefit cost ratio (BCR) } \\
\text { (iv } \div \text { iii) }\end{array}$ & 1.23 & 1.26 & 1.15 & 1.81 & 1.23 & 1.72 & 2.15 & 1.98 \\
\hline
\end{tabular}

Source: Authors' estimation, 2018.

\section{Households' intensity of poverty}

Multidimensional poverty index (MPI) was used to demonstrate the farmers' livelihood condition in the study areas in terms of appraising poverty circumstances. In this analysis, a basket of goods and services was considered as the minimum requirement to live a non-impoverished life. People who did not have an income sufficient to cover that basket were deemed as poor (HDR, 2015). The MPI combined two key pieces of information to measure acute poverty: the incidence of poverty or the proportion of people (within a given population) who experienced multiple deprivations, and the intensity of their deprivation - the average proportion of (weighted) deprivations they experienced.

Table 6. Multidimensional poverty index (MPI) to measure poverty intensity

\begin{tabular}{|c|c|c|c|c|c|}
\hline \multirow{4}{*}{ Indicators } & \multicolumn{4}{|c|}{ Study areas } & \multirow{4}{*}{ Weights } \\
\hline & \multicolumn{2}{|c|}{$\begin{array}{l}\text { Non-saline } \\
(\mathrm{n}=200)\end{array}$} & \multicolumn{2}{|l|}{$\begin{array}{l}\text { Saline } \\
(\mathrm{n}=300)\end{array}$} & \\
\hline & \multicolumn{4}{|c|}{$\begin{array}{l}\text { No. of households deprived }(\sqrt{ }) \text { or } \\
\text { privileged }(\times) \text { based on the indicators }\end{array}$} & \\
\hline & $\sqrt{ }$ & $x$ & $\sqrt{ }$ & $x$ & \\
\hline \multicolumn{6}{|l|}{ Education } \\
\hline No one has completed five years of schooling & $120 / 200$ & $80 / 200$ & $255 / 300$ & $45 / 300$ & $1 / 6$ \\
\hline
\end{tabular}




\begin{tabular}{|c|c|c|c|c|c|}
\hline \multirow{4}{*}{ Indicators } & \multicolumn{4}{|c|}{ Study areas } & \multirow{4}{*}{ Weights } \\
\hline & \multicolumn{2}{|c|}{$\begin{array}{l}\text { Non-saline } \\
(\mathrm{n}=200)\end{array}$} & \multicolumn{2}{|l|}{$\begin{array}{l}\text { Saline } \\
(\mathrm{n}=300)\end{array}$} & \\
\hline & \multicolumn{4}{|c|}{$\begin{array}{l}\text { No. of households deprived }(\sqrt{ }) \text { or } \\
\text { privileged }(\times) \text { based on the indicators }\end{array}$} & \\
\hline & $\sqrt{ }$ & $x$ & $\sqrt{ }$ & $x$ & \\
\hline $\begin{array}{l}\text { At least one school-age child not enrolled in } \\
\text { school }\end{array}$ & $113 / 200$ & $87 / 200$ & $197 / 300$ & $103 / 300$ & $1 / 6$ \\
\hline \multicolumn{6}{|l|}{ Health } \\
\hline At least one member is malnourished & $94 / 200$ & $106 / 200$ & $208 / 300$ & $92 / 300$ & $1 / 6$ \\
\hline One or more children have died & $12 / 200$ & $188 / 200$ & $34 / 300$ & $266 / 300$ & $1 / 6$ \\
\hline \multicolumn{6}{|l|}{ Living standards } \\
\hline No electricity & $55 / 200$ & $145 / 200$ & $86 / 300$ & $214 / 300$ & $1 / 18$ \\
\hline No access to clean drinking water & $49 / 200$ & $151 / 200$ & $100 / 300$ & $200 / 300$ & $1 / 18$ \\
\hline No access to adequate sanitation & $33 / 200$ & $167 / 200$ & $72 / 300$ & $228 / 300$ & $1 / 18$ \\
\hline House having dirty floor & $91 / 200$ & $109 / 200$ & $273 / 300$ & $27 / 300$ & $1 / 18$ \\
\hline $\begin{array}{l}\text { Household uses dirty cooking fuel } \\
\text { (i.e., cowdung, firewood or charcoal) }\end{array}$ & $200 / 200$ & $0 / 200$ & $300 / 300$ & $0 / 300$ & $1 / 18$ \\
\hline $\begin{array}{l}\text { Household has no car and owns at best one } \\
\text { bicycle, motorcycle, radio, refrigerator, mobile } \\
\text { or television }\end{array}$ & $55 / 200$ & $145 / 200$ & $112 / 300$ & $188 / 300$ & $1 / 18$ \\
\hline Score of the households & 0.417 & 0.583 & 0.560 & 0.440 & - \\
\hline Intensity of poverty Deprived households & 41.7 & & 56.0 & & - \\
\hline (\%) Privileged households & 58.3 & & 44.0 & & - \\
\hline
\end{tabular}

Source: Authors' estimation, 2018.

Note: Score of deprived households in non-saline areas $=(120 / 200 \times 1 / 6)+(113 / 200 \times 1 / 6)+(94 / 200 \times$ $1 / 6)+(12 / 200 \times 1 / 6)+(55 / 200 \times 1 / 18)+(49 / 200 \times 1 / 18)+(33 / 200 \times 1 / 18)+(91 / 200 \times 1 / 18)+$ $(200 / 200 \times 1 / 18)+(55 / 200 \times 1 / 18)=0.417$; score of households in non-saline areas $=(80 / 200 \times 1 / 6)+$ $(87 / 200 \times 1 / 6)+(106 / 200 \times 1 / 6)+(188 / 200 \times 1 / 6)+(145 / 200 \times 1 / 18)+(151 / 200 \times 1 / 18)+(167 / 200 \times$ $1 / 18)+(109 / 200 \times 1 / 18)+(0 / 200 \times 1 / 18)+(145 / 200 \times 1 / 18)=0.583$; scores of deprived or privileged households in saline areas were calculated accordingly; percentage of deprived households in non-saline areas $=0.417 \times 100=41.7$; percentage of privileged households in non-saline areas $=0.583 \times 100=$ 58.3 ; and percentage of deprived or privileged households in saline areas were calculated accordingly.

It is evident from Table 6 that in non-saline and saline areas, the proportion of deprived households was $41.7 \%$ and $56.0 \%$; and the proportion of privileged households was $58.3 \%$ and $44.0 \%$, respectively. The households were deprived or privileged based on all the indicators of a single dimension or at a combination of the indicators across dimensions. The reason for a better livelihood condition of households in non-saline areas compared to households in saline areas was that the farmers in non-saline areas could grow crop round the year in their cropland 
maintaining a variety of crop diversification, but the farmers in saline areas had limited scope for crop production due to high level of salinity in their cropland which ultimately reduced their income than the farmers in non-saline areas.

\section{CONCLUSION}

The present study has been undertaken to understand the context for practice change in dry season cropping in Southern Bangladesh. The study revealed that in the nonsaline areas, majority of the farmers followed the cropping patterns of Fallow Aman rice - Pulses, Fallow - Aman rice - Boro rice and Aus rice - Aman rice Pulses, whereas in saline areas, most of the farmers followed the cropping patterns of Fallow - Aman rice - Fallow, Fallow - Aman rice - Pulses and Fallow - Aman rice Chili/Maize/Rabi crops. These cropping patterns indicated that there is a lack of dry season crops in the study areas for which it is needed incorporating pulse crops in coastal Southern regions; and wheat in Southwest regions of Bangladesh to enhance crop intensification. Crop intensification analysis revealed that farmers in non-saline areas grow crops for more than two times per year in a particular crop land but it was less than two times in case of farmers in saline areas. Profitability of major crops was much higher in non-saline areas compared to saline areas. The study also indicated that farmers' poverty intensity in terms of deprivation of health, education and living standards in non-saline areas were reasonably lower with regard to farmers in saline areas.

\section{ACKNOWLEDGEMENTS}

The authors express their gratitude to the Australian Centre for International Agricultural Research (ACIAR) for giving financial support to conduct the research. This research has been done in line with the objectives of the project entitled 'Incorporating salt-tolerant wheat and pulses into smallholder farming systems in Southern Bangladesh (CIM-2014-076)'.

\section{REFERENCES}

ACIAR. (2011). Sustainable intensification of Rabi cropping in Southern Bangladesh using wheat and mungbean. Technical Reports: 78, Australian Centre for International Agricultural Research. Available at https://www.aciar.gov.au/file/76191/ download?token=TZFH3VOn (accessed on 21 December 2018).

Ahsan, M.E. (2013). Coastal zone of Bangladesh: Fisheries resources and its potentials. Lambert Academic Publishing, OmniScriptum AraPers GmbH, Haroldstraße, Düsseldorf, Germany.

Babatunde, R.O., Omotesho, O.A. and Sholotan, O.S. (2007). Factors influencing food security status of rural farming households in north central Nigeria. Agricultural Journal, 2(3): 351-357. 
BBS. (2015). Statistical Yearbook of Bangladesh, Bangladesh Bureau of Statistics, Statistics Division, Ministry of Planning, Government of the People's Republic of Bangladesh, Dhaka.

Bhaskar, S. (2009). Cropping intensity in India. Knowledge of agriculture. Available at http://knowledgeofagriculture.blogspot.com/2009/11/cropping-intensity-in-india.html (accessed on 14 November 2018).

DAE. (2015). Department of Agricultural Extension, Government of the People's Republic of Bangladesh, Dhaka.

Dillon, J.L. and Hardaker, J.B. (1993). Farm management research for small farmer development, FAO, Rome.

Hasan, M.K., Desiere, S., D’Haese, M. and Kumar, L. (2018). Impact of climate-smart agriculture adoption on the food security of coastal farmers in Bangladesh. Food Security, 10(4): 1073-1088.

Hossain, A.B.M. (2016). Current state of climate information application in the agriculture sector. Country paper presentation (Bangladesh), Climate Services Users Forum for Agriculture (CSUF-Ag2), Myanmar.

Hossain, M.S. and Majumder, A.K. (2018). Impact of climate change on agricultural production and food security: A review on coastal regions of Bangladesh. International Journal of Agricultural Research, Innovation and Technology, 8(1): 62-69.

Islam, M.M. and Uddin, M.T. (2014). Impact of GO-NGO support on crop intensification and food security in Sirajganj char areas. Bangladesh Journal of Crop Science, 25: 25-36.

Kabir, M.J. and Rawson, H.M. (2011). Crops to replace or sequence with wheat: Economics of Rabi crops and common rotations. In: Sustainable intensification of Rabi cropping in Southern Bangladesh using wheat and mungbean, 231-217.

Nahar, K. and Hamid, F. (2016). Salinisation in South-West region of Bangladesh: Economic impact on paddy production. IOSR Journal of Humanities and Social Science (IOSRJHSS), 21(4-II): 80-88.

Shahidullah, S.M., Talukdar, M.S.A., Kabir, M.S., Khan, A.H. and Nur-E-Elahi. (2006). Cropping patterns in the South East coastal region of Bangladesh. Journal of Agriculture and Rural Development, 4(1\&2): 53-60.

Shoaib, J.U.M. (2013). Best practices and procedures of saline soil reclamation systems in Bangladesh. In: Best practices and procedures of saline sgoil reclamation systems in SAARC countries. SAARC Agriculture Centre (SAC), Dhaka, Bangladesh.

Stigler, G.J. (1994). Production and distribution theories, New Jersey, United States of America.

UNB. (2017). United News of Bangladesh. Climate-Smart Agriculture in Coastal Bangladesh. The Daily Sun. Available at http://www.daily-sun.com/printversion/details/ 263723/2017/

10/24/ClimateSmart-Agriculture-in-Coastal-Bangladesh (accessed on 09 November 2018). 
Uddin, M.T. and Dhar, A.R. (2017). Conservation agriculture practice in Bangladesh: Farmers' socioeconomic status and soil environment perspective. International Journal of Economics and Management Engineering, 11(5): 1251-1259.

Uddin, M.T. and Dhar, A.R. (2018). Government input support on Aus rice production in Bangladesh: Impact on farmers' food security and poverty situation. Agriculture \& Food Security, 7(1): 1-15.

Uddin, M.T., Dhar, A.R. and Islam, M.M. (2016). Adoption of conservation agriculture practice in Bangladesh: Impact on crop profitability and productivity. Journal of the Bangladesh Agricultural University, 14(1): 101-112. 